\title{
Life Skills Development Training for Adolescent Girls at Risk-Rescued Devadasi Girls in Karnataka
}

\author{
Diptty Joseph* and Bino Thomas ${ }^{\dagger}$
}

\section{Abstract}

The positive evidences of life skills education among the young people in difficult circumstances have encouraged the researchers in imparting life skills education to the rescued devadasi adolescent girls in North Karnataka. The study was conducted in pre experimental research design without a control group of rescued devadasi girls by understanding their needs and gaps in life skills. The effectiveness of the programme was assessed using a standardized tool. 25 adolescent girls who were rescued from the devadasi system participated in the study. These girls were daughters' of active devadasi women from Raichur, Koppal, Bellary and Bijapur. The girls were provided life skills education by the researchers. Intervention programme was developed based on the 10 life skills laid out by the World Health Organization after integrating methodologies and contents specific to their life situation after a need assessment study using Life skills assessment scale. The results analyzed in SPSS version 18 , indicate that the programme was effective and displayed statistical significance in rendering the participants with Life skills. The study intends to highlight the importance of developing tailor made life skills programme for vulnerable groups and girls at risk.

* Development Focus, Bengaluru, India: diptty.joseph@gmail.com

† NIMHANS, Bengaluru, India; binonimhans@gmail.com 
Keywords: Life skills education, Rescued devadasi girls, Devadasi system, Difficult circumstances

\section{Introduction}

The word Devadasi which means a servant (Dasi) to God (Deva)is derived from the Sanskrit language. It refers to an age-old practice where young girls are drawn into prostitution in the name of religious practices (Goswami 2000). The system of devadasi is widely considered to be a social evil, a ritualized prostitution that is practiced in several parts of India. Although the Government of India has banned the practice in the years 1982, 1988 in different States (Rajagopal, 2016), many young girls are still pulled into this system under the name of religion (Gupta, 2013). It is difficult to obtain the accurate number of girls pushed inside the devadasi practice in the different districts in States especially in Southern parts of India. Therefore, the total number of devadasi girls actively involved in the system currently is not available. This is, mainly because the practice is mostly home centered. However, some of the surveys have identified that the number of young girls introduced into the devadasi system every year in India is around 1,000 to 10,000 (Chakraborthy, 2000). The latest available official data for some of the districts in Karnataka reveals that the number is about 23,000 (Karnataka State Women's Development Cooperation, 2007). The children trapped in devadasi system undergo serious human right violations in their lives including denial of their basic rights such as the right to education, right to avail health facilities and so on. This also includes sexual and reproductive health rights, thus limiting their physical and mental well being considerably in addition to various sexually transmitted diseases (Shamshad Khan, 2017). The rescued devadasi girls are vulnerable to maintain the traditional system of prostitution by social force, isolation, rejection and thus continue to be an isolated group with less dignity and worth of life in the society in the absence of interventions that include skills training, education and rehabilitation. The socio cultural factors that maintain the continued practice of devadasi also could be explained in the context of the existing political and social insensitivities. 
In the state of Karnataka, devadasis is a group of individuals who are excluded, ignored, and out caste from the village. They live in very poor and degraded conditions and have a very low socio economic status (Orchard, 2007). Discrimination, social exclusion and stigma are some of the worst situations faced by them. These issues furthermore manifest in them as depression and other abnormal behaviors. The victims are reported to have experienced severe mental trauma due to physical violence and threats. Though the practice was declared unlawful with Madras Devadasi (Prevention of Dedication) Act 1947, Karnataka Devadasi (Prohibition of Dedication) Act, 1982,Andhra Pradesh Devadasi (Prevention of Dedication) Act, 1988, and Maharashtra Devadasi (Abolition of Dedication) Act 2006 at least a girl from a devadasi family is inevitably introduced into the system each year. The causes for temple dedication are different at various locations. Absence of a male child in the family (Tarachand, 1992), difficulties of mothers to raise the children, absence of a legal father (Deepa 2016) and inadequate efforts and responsibility of the State at large to bring this marginalized group to the main stream are associated factors for the continued practice of devadasi. In addition, both State and Central Government have not been successful in preventing devadasi dedication in temples (Kaneva 2016).This social evil despite the laws, has become a thriving business in a number of Union territories, and in Karnataka, Andhra Pradesh and Maharashtra (Kaneva, 2016). The Supreme Court has condemned the illegal practice of dedicating young girls as devadasi in the year 2016. Subsequently, the Union Government issued advisory to all States and Union Territories to stop illegal activities of subjecting young girls into the Devadasi system, as it is unethical practice. The apex court started hearing on the issue when apprised of how Dalit girls were dedicated as Devadasis in Uttangi Mala Durga Temple in Davanagere district of Karnataka (Rajagopal, 2016).Women enter into this practice at a very young age and by nature of their engagements as devadasi and subsequent ways of life they are not included in the larger society, and their socially ascribed lower moral standards become a hazard for their future life itself. Such a long duration of life in social rejection has found to be associated with depression and abnormal 
behavioral patterns in addition to psychosomatic problems (Kersenboom 1987) among devadasis.

Saying 'no' to devdasi practice or dedication under extreme pressure from relatives or other influential religious persons demands lots of courage, willpower and decision-making on personal ground and support and care from family and society. To withstand an environment that prescribed 'dedication' as the only choice in life, stresses a lot on competence of the young girls. Not every girl has the will power, courage and supportive environment to deal with such extreme conditions in life and take decisions for oneself. Training in life skills is an important method to nurture and enhance psycho social competencies among these young girls to prepare them to develop as capable women to better manage their life situations (Vini K, K; 2010).

In general, life skills training is found to have empowered young children in many ways; improved coping abilities and problems solving skills among rural adolescent girls in Dharawad rural district in Northern Karnataka (Pujar, Hunshal, \& Bailur2014), positive outcomes among the children from tribal background (Sangeeta, 2011), empowerment among economically weaker sections (Sangeeta and Bhamini, 2012), positive effect among girls in urban slums (Rajib 2009), significant impact in their lives and understanding about life skills among adolescents (Parvathy and Pillai 2015) in addition to higher level of knowledge on risk factors (Mathew, 2011).

More specifically, life skill training helped in developing adaptive behavior in rescued devadasi girls (Sathyanarayana T, N; 2012), psychosocial support helped to rebuild their self-confidence and help them cope with anxiety and depression (USAID, 2007), and higher self esteem among the children of Devdasis (Puthenveedu, 2016) in Karnataka State, (in a different district).

Enhancing the human capacity (PWG, 2003) is one way towards nurturing resilience, increasing participation and contribution of these young women in community. Life skills training have a significant role in enhancing such human capacities. Changes in these young girls could happen through improving skills attributed to social capabilities, attainment in education and job prospects. 
Life skills as life coping skills generally focus on the basic human development, which will equip them to face their challenges ahead. Intervention has always been a key element in social work research initiatives. A structured programme in life skills is hypothesized to help these young girls to enhance their self esteem, empower them with confidence and inculcate in them better decision making abilities regarding their life choices. Availability of literature is meager in the area of interventions with this group even in wide practice of the same despite regulations.

The participants of the study were children of devadasi and those who were dedicated as devadasi and got them rescued by nongovernmental organizations. Participants came from neighbouring districts such as Raichur, Bijapur, Bagalkot, and Bellary. They were part of a project of the organization that provided residential care and schooling for these girls for a brief period. After they complete the residential care programme and schooling they are expected to go back to their mothers or stay in the larger community with relatives.

These children are not provided any kind of training to deal with their vulnerabilities in the community. There is a high chance for themto revert back to the practice of devadasi or to prostitution by succumbing to the pressure from their mothers or community at large. This intervention of life skills is expected to provide them with essential skills, self-confidence and abilities to decide for oneselfand withstand these pressures.

\section{Methods}

The research is carried out in two phases one exploring their needs and the other providing interventions. The study included a single group pretested and exposed to the intervention and then post tested. Data was collected from 25 adolescent girls (12-16 years of age and daughters of devadasi) rescued from devadasi practice. These girls were provided residential care inthe nongovernmental organization that has a Programme for girls at risk or dedicated as devadasis, located at Koppal in Northern Karnataka. The intervention took place in a locality that facilitates an apparent platform for devadasi practice. Semi structured interview schedule to assess the socio demographic data (age, education, duration of 
stay in the institution, academic scores, contact with the family etc.) and Life Skills Assessment Scale (Vranda, 2009)to assess the life skills among the adolescents were the primary tools of data collection. The areas assessed included capacity to make decisions, problem solving, empathy, self awareness, skills related to interpersonal relationships, communication skills, and capacity to cope with stress, capacity to cope with emotions, creative thinking and critical thinking. The internal consistency coefficient alpha for the overall scale was 0.94 . The test - retest reliability coefficient ranged from 0.70 to 0.95 and overall reliability co-efficient was 0.96 indicated a high degree of temporal stability of the scale. The life skills assessment scale has also demonstrated strong construct aspect of content validity, discriminate validity and concurrent validity. This scale was developed and standardized among the institutional children in Karnataka. The language of the tool was Kannada, the vernacular language for participants of this study. Descriptive statistics, such as mean and standard deviation were used to describe the characteristics of the sample. Normality test was done to confirm normal distribution of data. The effectiveness of intervention were analyzed with the help of Paired sample' $t^{\prime}$ test. SPSS version 18 was used to analyze the data.

\section{Details of the intervention Programme}

The goal of the intervention was to help the rescued devadasi adolescent girls enhance their life skills through structured and systematic activities. The content of the programme was prepared from the existing literatures, discussion with experts and on the basis of the findings of the phase one need assessment. The experts consisted of members who were life skills trainers, academicians and mental health professionals who practiced in the areas of life skills and adolescents in difficult circumstances. The content of the intervention focused on personal, interpersonal and societal skills, which would empower the young girls in addressing the deeprooted religious and traditional practice of devadasi system in their communities. Three experts who were academicians and practitioners validated the programme content. The recommendations from experts emphasized on the protection of rights and development of the personality in the content of the intervention. 
Diptty and Bino Life Skills Development Training for Adolescent Girls

Table 1 Life Skills Intervention for adolescent girls at risk

\begin{tabular}{|c|c|c|c|}
\hline Sl. No & Session no.\& Name & Duration & Methods \\
\hline 1 & Session 1 Introduction & $\begin{array}{c}60 \\
\text { minutes }\end{array}$ & $\begin{array}{l}\text { Group discussion and } \\
\text { activities }\end{array}$ \\
\hline 2 & Session 2 Self Awareness & $\begin{array}{c}90 \\
\text { minutes }\end{array}$ & $\begin{array}{l}\text { Group discussion, role } \\
\text { play }\end{array}$ \\
\hline 3 & Session 3 Communication & $\begin{array}{l}105 \\
\text { minutes }\end{array}$ & $\begin{array}{l}\text { Group discussion, } \\
\text { activities, role play }\end{array}$ \\
\hline 4 & $\begin{array}{l}\text { Session } 4 \text { Interpersonal } \\
\text { Relationship }\end{array}$ & $\begin{array}{c}60 \\
\text { minutes }\end{array}$ & $\begin{array}{l}\text { Group discussion and } \\
\text { group activity }\end{array}$ \\
\hline 5 & Session 5 Self Esteem & $\begin{array}{c}90 \\
\text { minutes }\end{array}$ & $\begin{array}{l}\text { Group discussion and } \\
\text { group activities }\end{array}$ \\
\hline 6 & Session 6 Decision Making & $\begin{array}{c}90 \\
\text { minutes }\end{array}$ & $\begin{array}{l}\text { Lecture, group activity, } \\
\text { group discussion }\end{array}$ \\
\hline 7 & Session 7 Problem Solving & $\begin{array}{l}90 \\
\text { minutes }\end{array}$ & $\begin{array}{l}\text { Lecture, Group } \\
\text { discussion, role play, } \\
\text { group activities }\end{array}$ \\
\hline 8 & Session 8 Critical Thinking & $\begin{array}{c}90 \\
\text { minutes }\end{array}$ & $\begin{array}{l}\text { Lecture, Individual } \\
\text { activity }\end{array}$ \\
\hline 9 & Session 9 Making Plans & $\begin{array}{c}90 \\
\text { minutes }\end{array}$ & $\begin{array}{l}\text { Group discussion, and } \\
\text { lecture }\end{array}$ \\
\hline 10 & Session 10 Bringing all Together & $\begin{array}{c}60 \\
\text { minutes }\end{array}$ & $\begin{array}{l}\text { Group activity and } \\
\text { Presentations }\end{array}$ \\
\hline
\end{tabular}

\section{Phases of Study}

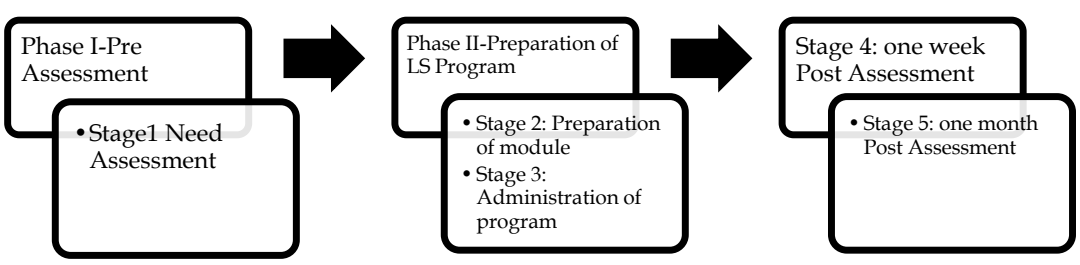

\section{Phase I: Pre- assessment}

An introductory session was taken by the researchers to introduce the topic. The process of study was explained to them. The questionnaire was a self-administered one. The participants were given clear and adequate instructions. The socio demographic questionnaire was also administered at this phase.

$50 \%$ of the participants were of 13 years of age, $23 \%$ participants were aged 14 years, 20\% were aged 12 years and $7.7 \%$ represented 15 years of age. Almost $80 \%$ of the participants were from high school studying in grade 8 or 9. Half $(50 \%)$ of the participants' 
primary caretaker was their mother. All the youngsters were children of Devadasi.

\section{Phase II: Preparation of life skills programme}

The pre assessment scores reflected very low scores on almost all dimensions of life skills among the participants. The programme approach was to provide a platform to develop psychosocial competencies among the girls through interactive learning. The results of the first phase indicated that social customs along with economic pressures forced many into this system. All the participants of this study were children to their devadasi mother born out of wedlock. Most of the children reported they were affected and stigmatized. Teaching life skills as generic skills seemed to be enabling these participants to transform knowledge and attitudes along with values into actual abilities. The methodology adopted to impart the training was through a series of diverse interactive sessions and activities. All the activities were tailor made to improve their own experiential learning. Activities involved learning to take cue from others behaviour; improve their communication, roles plays, journals writing, activities to improve their self-confidence, critical and creative thinking, decision making abilities. The programme provided participants with opportunities to develop as strong and confident young women. The sessions and activities were intended to be useful for adolescent girls in the age group ranging from 12 to 16 . The curriculum had taken an interactive approach, using a variety of games, role-plays, small group activities and discussions based on their learning abilities. This programme became compatible, when tailor made for identified target group based on their felt and expressed needs. The program was simple, age appropriate for the adolescent group and most importantly included activities that the participants could relate to their day today events. Helping them build upon how they learn from their own experiences, from people around them provided a better methodology for change towards becoming confident, strong young women.

The programme (Table No. 1) consisted of ten sessions based on the life skills, they are: introduction to the Programme, feelings (self awareness), communication, listening and feedback, skills of 
interpersonal relationships, healthier relationships, self esteem, capacity to make decisions, resolving conflicts, problem solving, setting goals, critical thinking, making plan, teamwork and bringing it all together.

The life skills programme was administered to the participants over a span of two days. This included five sessions in a day and covered ten sessions in two days. Out of the 31 participants screened in the pre assessment 25 were within the age and were children of devadasis. Evaluation was carried out after each session. There were breaks of 10 minutes between each session along with break for lunch. An observer, a development professional was present throughout the programme and gave feedback after each individual session and about the whole programme in the end. This helped the researchers improve their own skills in conducting similar sessions.

\section{Phase III: Post- assessment}

The first Post Assessment of life skills of the participants took place one week after the intervention programme and the second after a month. A brief introduction about the purpose of post assessment was explained each time when two post assessments were made.

\section{Results and Discussions}

The results were positive and indicated an improvement in the level of life skills among the participants due to the Intervention.

The level of life skills among the participants before the Intervention

Table 2 Distribution of level of Life Skills - Dimension wise in Pre-assessment

\begin{tabular}{llccc}
\hline Sl.No. & \multicolumn{1}{c}{ Life Skills } & Low & Moderate & High \\
\hline 1 & Decision Making & $21(81 \%)$ & $5(19 \%)$ & 0 \\
2 & Problem Solving & $16(62 \%)$ & $9(35 \%)$ & $1(4 \%)$ \\
3 & Empathy & $21(81 \%)$ & $5(19 \%)$ & 0 \\
4 & Self Awareness & $16(62 \%)$ & $8(31 \%)$ & 0 \\
5 & Communication & $13(50 \%)$ & $12(46 \%)$ & $1(4 \%)$ \\
6 & Interpersonal & $15(58 \%)$ & $9(35 \%)$ & $2(8 \%)$ \\
7 & Coping with emotions & $15(58 \%)$ & $10(38 \%)$ & $1(4 \%)$ \\
\hline
\end{tabular}




\begin{tabular}{llccc}
\hline 8 & Coping with Stress & $14(54 \%)$ & $11(42 \%)$ & $1(4 \%)$ \\
9 & Creative Thinking & $10(38 \%)$ & $8(31 \%)$ & $8(31 \%)$ \\
10 & Critical Thinking & $14(54 \%)$ & $12(46 \%)$ & 0 \\
\hline
\end{tabular}

Table 2 describes a detailed level of life skills in each dimension of pre assessment scores. Participants displayed low levels in all dimension of life skills except for creative thinking where they scored comparatively high. Only 10 participants remained at the low level in creative thinking. There were 8 who scored moderate and high respectively.

Table 3 Phases of intervention and level of significance

\begin{tabular}{|c|c|c|c|c|}
\hline Decision making skill & Mean & $\begin{array}{l}\text { Standard } \\
\text { deviation }\end{array}$ & T-value & $\begin{array}{l}\mathrm{p} \text {-value/ } \\
\text { significance } \\
\text { value }\end{array}$ \\
\hline Before the intervention & 31.69 & 2.363 & \multirow[b]{2}{*}{-1.985} & \multirow[b]{2}{*}{$0.029^{*}$} \\
\hline $\begin{array}{l}\text { One week after } \\
\text { intervention }\end{array}$ & 33.65 & 5.161 & & \\
\hline Before the intervention & 31.69 & 2.363 & \multirow[b]{2}{*}{-2.492} & \multirow[b]{2}{*}{$0.010^{*}$} \\
\hline $\begin{array}{l}\text { One month after } \\
\text { intervention }\end{array}$ & 33.85 & 4.610 & & \\
\hline Problem Solving Skill & Mean & $\begin{array}{l}\text { Standard } \\
\text { deviation }\end{array}$ & t- value & $\begin{array}{c}\mathrm{p} \text {-value/ } \\
\text { significance } \\
\text { value }\end{array}$ \\
\hline Before the intervention & 44.00 & 4.317 & \multirow[b]{2}{*}{-3.229} & \multirow[b]{2}{*}{$0.001^{*}$} \\
\hline $\begin{array}{l}\text { One week after } \\
\text { intervention }\end{array}$ & 48.04 & 6.648 & & \\
\hline Before the intervention & 44.00 & 4.317 & \multirow[b]{2}{*}{-4.016} & \multirow[b]{2}{*}{$0.000^{*}$} \\
\hline $\begin{array}{l}\text { One month after } \\
\text { intervention }\end{array}$ & 49.12 & 6.501 & & \\
\hline Empathy & Mean & $\begin{array}{l}\text { Standard } \\
\text { deviation }\end{array}$ & t- value & $\begin{array}{l}\mathrm{p} \text {-value/ } \\
\text { significance } \\
\text { value }\end{array}$ \\
\hline Before the intervention & 38.35 & 3.622 & \multirow[b]{2}{*}{-2.920} & \multirow[b]{2}{*}{$0.004^{*}$} \\
\hline $\begin{array}{l}\text { One week after } \\
\text { intervention week after } \\
\text { intervention }\end{array}$ & 42.35 & 5.706 & & \\
\hline Before the intervention & 38.35 & 3.622 & \multirow[b]{2}{*}{-3.183} & \multirow[b]{2}{*}{$0.002^{*}$} \\
\hline $\begin{array}{l}\text { One month after } \\
\text { intervention }\end{array}$ & 42.92 & 6.131 & & \\
\hline
\end{tabular}


Diptty and Bino Life Skills Development Training for Adolescent Girls

\begin{tabular}{|c|c|c|c|c|}
\hline Self- awareness & Mean & $\begin{array}{l}\text { Standard } \\
\text { deviation }\end{array}$ & t- value & $\begin{array}{l}\mathrm{p} \text {-value/ } \\
\text { significance } \\
\text { value }\end{array}$ \\
\hline $\begin{array}{l}\text { Before the } \\
\text { intervention }\end{array}$ & 31.88 & 3.229 & \multirow{3}{*}{-7.619} & \multirow{3}{*}{$0.000^{*}$} \\
\hline $\begin{array}{l}\text { One week after } \\
\text { intervention }\end{array}$ & 38.58 & 3.859 & & \\
\hline $\begin{array}{l}\text { One month after } \\
\text { intervention }\end{array}$ & 38.54 & 5.054 & & \\
\hline $\begin{array}{l}\text { Communication } \\
\text { Skills }\end{array}$ & Mean & $\begin{array}{l}\text { Standard } \\
\text { deviation }\end{array}$ & t- value & $\begin{array}{c}\mathrm{p} \text {-value/ } \\
\text { significance } \\
\text { value }\end{array}$ \\
\hline $\begin{array}{l}\text { Before the } \\
\text { intervention }\end{array}$ & 31.88 & 3.229 & \multirow[b]{2}{*}{-7.619} & \multirow[b]{2}{*}{$0.000^{*}$} \\
\hline $\begin{array}{l}\text { One week after } \\
\text { intervention }\end{array}$ & 38.58 & 3.859 & & \\
\hline $\begin{array}{l}\text { Before the } \\
\text { intervention }\end{array}$ & 31.88 & 3.229 & \multirow[b]{2}{*}{-5.559} & \multirow[b]{2}{*}{$0.000^{*}$} \\
\hline $\begin{array}{l}\text { One month after } \\
\text { intervention }\end{array}$ & 38.54 & 5.054 & & \\
\hline $\begin{array}{l}\text { Interpersonal } \\
\text { Relationships }\end{array}$ & Mean & $\begin{array}{l}\text { Standard } \\
\text { deviation }\end{array}$ & t- value & $\begin{array}{c}\text { p-value/ } \\
\text { significance } \\
\text { value }\end{array}$ \\
\hline $\begin{array}{l}\text { Before the } \\
\text { intervention }\end{array}$ & 62.46 & 5.376 & \multirow{3}{*}{-4.540} & \multirow{3}{*}{0.000} \\
\hline & & & & \\
\hline $\begin{array}{l}\text { One week after } \\
\text { intervention }\end{array}$ & 68.92 & 6.066 & & \\
\hline $\begin{array}{l}\text { Before the } \\
\text { intervention }\end{array}$ & 62.46 & 5.376 & \multirow{2}{*}{-5.114} & \multirow{2}{*}{$0.000^{*}$} \\
\hline $\begin{array}{l}\text { One month after } \\
\text { Intervention }\end{array}$ & 69.73 & 5.855 & & \\
\hline $\begin{array}{l}\text { Coping with } \\
\text { Emotions }\end{array}$ & Mean & $\begin{array}{l}\text { Standard } \\
\text { deviation }\end{array}$ & t- value & $\begin{array}{c}\mathrm{p} \text {-value/ } \\
\text { significance } \\
\text { value }\end{array}$ \\
\hline $\begin{array}{l}\text { Before the } \\
\text { intervention }\end{array}$ & 29.69 & 4.398 & \multirow[b]{2}{*}{-5.015} & \multirow[b]{2}{*}{0.000} \\
\hline $\begin{array}{l}\text { One week after } \\
\text { intervention }\end{array}$ & 34.69 & 4.193 & & \\
\hline $\begin{array}{l}\text { Before the } \\
\text { intervention } \\
\text { One month after } \\
\text { intervention }\end{array}$ & 35.15 & 5.259 & -5.003 & 0.000 \\
\hline
\end{tabular}




\begin{tabular}{|c|c|c|c|c|}
\hline Coping with Stress & Mean & $\begin{array}{l}\text { Standard } \\
\text { deviation }\end{array}$ & t- value & $\begin{array}{c}\text { p-value/ } \\
\text { significance } \\
\text { value }\end{array}$ \\
\hline $\begin{array}{l}\text { Before the } \\
\text { intervention }\end{array}$ & 30.27 & 3.027 & \multirow{2}{*}{-2.67} & \multirow[b]{2}{*}{0.006} \\
\hline $\begin{array}{l}\text { One week after } \\
\text { intervention }\end{array}$ & 32.62 & 3.900 & & \\
\hline $\begin{array}{l}\text { Before the } \\
\text { intervention }\end{array}$ & 30.27 & 3.027 & \multirow{2}{*}{-3.121} & \multirow{2}{*}{0.005} \\
\hline $\begin{array}{l}\text { One month after } \\
\text { intervention }\end{array}$ & 32.92 & 3.773 & & \\
\hline Critical thinking & Mean & $\begin{array}{l}\text { Standard } \\
\text { deviation }\end{array}$ & t- value & $\begin{array}{c}\mathrm{p} \text {-value/ } \\
\text { significance } \\
\text { value }\end{array}$ \\
\hline $\begin{array}{l}\text { Before the } \\
\text { intervention }\end{array}$ & 49.38 & 6.191 & \multirow[b]{2}{*}{-3.82} & \multirow[b]{2}{*}{$0.000^{*}$} \\
\hline $\begin{array}{l}\text { One week after } \\
\text { intervention }\end{array}$ & 53.58 & 7.553 & & \\
\hline $\begin{array}{l}\text { Before the } \\
\text { intervention }\end{array}$ & 49.38 & 6.191 & \multirow{2}{*}{-1.736} & \multirow{2}{*}{$0.047^{*}$} \\
\hline $\begin{array}{l}\text { One month after } \\
\text { intervention }\end{array}$ & 52.27 & 8.273 & & \\
\hline Creative thinking & Mean & $\begin{array}{l}\text { Standard } \\
\text { deviation }\end{array}$ & $\begin{array}{c}\mathrm{T}- \\
\text { value }\end{array}$ & $\begin{array}{c}\mathrm{p} \text {-value/ } \\
\text { significance } \\
\text { value }\end{array}$ \\
\hline $\begin{array}{l}\text { Before the } \\
\text { intervention }\end{array}$ & 32.19 & 3.899 & \multirow{2}{*}{$\begin{array}{c}- \\
2.791\end{array}$} & \multirow{2}{*}{0.005} \\
\hline $\begin{array}{l}\text { One week after } \\
\text { intervention }\end{array}$ & 36.92 & 4.971 & & \\
\hline $\begin{array}{l}\text { Before the } \\
\text { intervention }\end{array}$ & 32.19 & 3.899 & \multirow{2}{*}{1.648} & \multirow{2}{*}{0.056} \\
\hline $\begin{array}{l}\text { One month after } \\
\text { intervention }\end{array}$ & 35.12 & 7.328 & & \\
\hline
\end{tabular}

Table 3 reveals the results between Pre assessment and Post Assessment one and Pre Assessment and Post Assessment two. The mean scores of all 10 dimensions of life skills, with standard deviation before and after interventions are shown in the table. After one week of intervention, the average scores improved, with corresponding standard deviation. The $t$ value of paired $t$ - test and $\mathrm{p}$ - value are shown in the dimensions. In all dimensions, $\mathrm{p}$ values 
are less than 0.05 . The results show that there is a significant improvement in the level of life skills among the rescued Devadasi adolescent girls. The rescued devadasi girls in the Programme had improved on their coping skills and adjustment skills.

This programme helped in increasing the confidence level, emotional stability, social responsibility and empathy among the devadasi rescued girls as against the institutionalized adolescent children (Brunelle, 2009, Ashwini, 2011). Life Skills Education as in the context of empowering the adolescents (Bharath \& Kumar, 2010, Vini 2010) could be used among the rescued devadasi girl at prevalent places.

All these young participants were from rural background and they continue to live in an environment, which is not different from the place where they were raised. It requires significant amount of self confidence and ability to withstand the stigma and discrimination. This intervention, though has not addressed the social issues, but has given enough opportunities for the young girls to learn skills for self-development. Creative and critical thinking, which are very important from the cognitive life skills paradigm, have considerably contributed to reducing the level of stress in the school and raising the level of self confidence among adolescents in this study as well.

The results give a possible idea for practice to enable and empower the young girls who are rescued from this traditional form of prostitution. This enabling process was a good start for these young girls' rehabilitation and reintegration to thier own communities. The skills they developed is expected to help themaddress issues that they face and enable them in taking decisions for themselves.

\section{Conclusion}

The study emphasizes on the current state of adolescent girls who are rescued from to Devadasi practice in Karnataka. Since this practice is deep-rooted in various traditions and rituals, prevention and eradication needs work from different sector of the society. Developing competencies among these young girls was one form of empowerment to allow them to live with heads high and heart strong. Study results stress on the need of training rescued 
devadasi girls in Life skills as an important method to nurture and enhance psycho-social competencies and to equip them to develop as young women capable enough to manage their life situations. The training has been found feasible and useful in bringing a positive transformation in their outlook. The rescued girls have shown changes in the knowledge and the way they have applied it in their lives. NGOs working in the field and Social Work professionals, mental health professionals and other helping professionals working towards the up-liftment of rescued Devadasi girls can find this programme as an evidence to strengthen the rescued Devadasi girls through competency building. Therefore, it has given enough opportunities for the young girls to learn skills for self-development. Further evidence based research is suggested with a delayed post evaluation to understand their abilities in real life situations after such interventions.

* Acknowledgements: The study was conducted when the first author was an MPhil research scholar at Department of Social Work and the second author Associate Professor of Social Work at Christ University, Bengaluru. The authors thank the management of Christ University and the organization for the conduct of study.

\section{Reference:}

Ashwini, K.M. (2011). Impact of Life Skills training among Institutionized Children, MPhil Dissertation (unpublished), Christ University, Bangalore.

Bharath, S., \& Kumar K,V. (2010). Empowering Adolescents with Life Skills Education in Schools- School Mental Health Pirogram: Does it work?, Indian Journal of Psychiatry, 344-349.

Brunelle, D. (2009). The Impact of a Sport Based Life Skills Program on Adolecent Prosocial Values. Applied Development Science, 11(1), 43-55.

Chakraborthy, K. (2000). Women as Devadasis Origin and Growth of the Devadasi Profession. New Delhi, New Delhi: Deep \& Deep Publications, Ltd., Pvt.

Deepa, B and Suvarnasuni, D (2016). Devadasi system: forced prostitution by Dalit women on the name of religion. Internatinoal journal of resaerch in humanities, arts and literature. 4(2), 63-70. ISSN (P) 23474564.

Goswami K P. Devadasi. Dancing damsel. New Delhi: APH Publishing Corporation; 2000 
Gupta, I. (2013, April 30). www.academia.edu. Retrieved 2015, from http://www.academia.edu/7856458/Perceptions_of_Prostitution_Th e_Devadasi_System_in_India

Kaneva, A. (2016). Putting and end to ritualised prostitution in India: What will it take?. Retrieved from http:// www.internationalwomensinitiative.org/news/2016/3/24/puttingan-end-to-ritualised-prostitution-in-india-what-will-it-take. on 24 August.

Karnataka State Women's Development Cooperation. (2007). Karnataka State women's Development Corporation figures on devadasi as mentioned in 'Women Devadasi in, Jogini and Mathamma in Karnataka and Andhra Pradesh, Southern India,ritual slavery',2007.Retrieved from www.antislavery.org.

Kersenboom S. Nityasumangali (1987). In Sathyanarayana T N, B. G. (2012). Targeted sexual exploitation of children and women in India: Policy perspectives on Devadasi system. Annals of Tropical Medicine and Public Health, 5 (3), 157-162.

Mathew. L., \& Thote, P. (2011).Study of preference of life skills: A case study. Indian Journal of Life Skills Education, 2 (2), 343-358.

Orchard, T. (2007). Girl, Women, Lover, Mother. Towards a new understanding of child prostitution among young devadasi in rural Karnataka, India. Journal of Social science and Medicine , 2379-2390.

Pai. (2011). Life Skills Education for School Effectiveness and Improvement. Around table presentation at International congress for school effectiveness and improvement.Florida: www.docstoc.com.

Parvathy V and Renjith RP (2015).Impact of life skills education on adolescents in rural school. International Journal of Advanced Resaerch.3 (2). ISSn 2320-5407

Pujar, L., Hunshal, H., \& Bailur, K. (2014, March). Impact of intervention on life skill development among adolescent girls. Karnataka Journal of Agricultural Sciences, 93-94.

Puthenveedu, K and Kasi S. (2016). Efficacy of psychosocial intervention on self esteem among children of unwed mothers. Joint world conference on Social Work, Education and Social Develpemnt. Jan 2017, Seoul, Korea

PWG.Psychosocial working group framework (2003).In Sathyanarayana T N, B. G. (2012). Targeted sexual exploitation of children and women in India: Policy perspectives on Devadasi system. Annals of Tropical Medicine and Public Health, 5 (3), 157-162

Rajagopal, K. (2016, Feb 13). The dedication of Devadasis still prevails in Davanagere district of Karnataka. The Hindu .

Rajib Acharya (2009): Broadening girls" horizons: Effects of a life skills education programme in rural Uttar Pradesh, Population Council. In 
Parvathy V and Renjith RP (2015).Impact of life skills education on adolescents in rural school. International Journal of Advanced Resaerch 3 (2). ISSn 2320-5407

Sangeeta Chaudhary \& Bhamini Mehta., (2012): Life Skill Education for the economically backward adolescent boys and girls: An Intervention Programme, International Journal of Social Sciences $\mathcal{E}$ Interdisciplinary Research, 1(5).

Sangeeta, C.,\& Mehta, B. (2011). Life Skills Education for Tribal Adolescents: An Intervention Study, Indian Journal of Life Skills Education, 2 (2), 342-358.

Sathyanarayana T N, B. G. (2012). Targeted sexual exploitation of children and women in India: Policy perspectives on Devadasi system. Annals of Tropical Medicine and Public Health, 5 (3), 157-162.

Shamshad Khan, R. L. (2017, May 19). http://www.tandfonline.com/ doi/abs/10.1080/ 17441692.2017. 1280070. Retrieved from http://www.tandfonline.com/:http://www. tandfonline.com/ doi/ abs/10.1080/17441692.2017.1280070

Tarachand, K. C. (1992). Devadasi custom: Rural social structure and flesh market. Socialogical publication in Hornour of Dr.K Ishwaran.

USAID. (2007). A Study Conducted Pursuant to the Trafficking Victim Protection. USA: Office of Women in Development, USAID.

Vini,K.K. (2010). Life Skills Program for Adolecents in SOS village. Unpublished M.Phil Disertation. Bangalore: NIMHANS.

Yankey, Biswas. (2012). Life Skills Training as an Effective Intervention Strategy to reduce Stress among Tibetan Refuge Adolecents. Journal of Refugee Studies, doi: 10.1093/jrs/fer056. Rerived on 23 sep 2012. 